\title{
Developing Inquiry Model-Based Device to Increase Learning Results Skill Writing a Scientific Balance of Biology Projects
}

\author{
Elsje Theodora Maasawet ${ }^{1}$, Wahyu Sekti Retnaningsih ${ }^{2}$, Didimus Tanah Boleng ${ }^{3}$ \\ Department of Biology Education, Faculty of Teacher Training and Education, Mulawarman University, Indonesia \\ emaasawet@gmail.com, didimus.tanahboleng@yahoo.mail
}

\begin{abstract}
Success in the learning process is not only judged from the ongoing process but ongoing processes and learning models that meet the needs of the students. The learning model helps teachers in classroom teaching especially practitioners writing scientific reports. One way to solve this problem is to use the Inquiry learning model. The purpose of this Research and Development research is to design and develop the Inquiry learning model by assessing the validity / quality, practicality and effectiveness in the learning process of Biological Sciences for grade VIII students. The development procedure was carried out by adopting Borg and Gall's modified development design by Sugiyono consisting of nine stages: identification of problem and potential, data collection and product design, validation of Design expert, design revision, product trial, product revision one, second product revision, and final product. The validity and practicality of the product were analyzed using the percentage improvement of the students' pretest and posttest scores. Product validation is very good $(97.11 \%$ improvement), the practicality measured through the assessment of respondents is also very practical $(87.37 \%)$. In conclusion, Inquiry learning model able to give skill to students and positive impact in writing scientific report so that their learning more effective with $34,74 \%$.
\end{abstract}

Keywords-Development; Inquiry Learning Model; Scientific Writing Skills

\section{INTRODUCTION}

Learning is a process done by individuals to obtain a result of changes in behavior, whether observed or not directly observed. Teacher learning process, does not have to be fixed by using a single method or learning strategy, a teacher is able to use various methods or learning strategies so that in teaching and learning activities are not boring for students and in accordance with the goals to be achieved is the achievement of increased motivation and learning achievement [6]. Success in the learning process is not only judged by the ongoing process but ongoing processes. The essence of improving the quality of education is the occurrence of quality improvement in the learning process.

Biology learning seems troublesome because many memorize the scientific names, the reading is long and the material is hard to understand. But the negative impression is gradually began to fade with the fun learning process that is learning to blend with nature, examine / explore the advantages of the surrounding natural environment, and can find creative ideas by written in scientific papers

Biology Learning emphasizes the direct experience that can be gained from everyday life, the environment, and a society loaded with technology. In biology learning needs to be developed scientific process that can encourage students in solving a problem in learning process, in this case is practicum activity done both inside and outside class [5]. Daily learning is inseparable from complementary learning complementary to syllabus, lesson plan, teaching material, instructional media, student worksheet and evaluation instrument [8].

Learning model is a guide or direction for teachers. This is just as important as the teaching-learning process, which must be systematic and pattern-oriented. Recently, most teachers have either been misguided or confused themselves in the middle of their teaching-learning process simply because they do not have explicit learning models to teach. A model of learning, however, can provide guidance on what the teacher should do in the classroom, in addition to the fact that this book gives him or guides how to develop teaching techniques and how to design better learning models [10].

The results of observation and interview on the analysis of needs in State Junior High School 12 Samarinda showed that the three schools have been using educational unit curriculum (KTSP). Biology Science Teachers claim that their students are less active and creative in understanding the material so that teachers are facing difficulties when using cooperative learning models in the classroom. Teachers are less able to adapt themselves to the model of learning with the condition of their students who have diverse skills today in school.

The teacher also ensured that the students' scientific writing skills skills were still less than observed after the practice where they lacked understanding of the scientific report writing steps. Such difficulties will not be faced by the teachers in the classroom during the learning process if the teaching component is well prepared [11]. This type of learning model is focused on improving learning outcomes and writing skills of scientific reports using the Inquiry model.

The Inquiry Learning Model is a series of learning activities that involves maximally all the learners' ability to search and investigate systematically, critics, and logical so 
that they can find their own knowledge, attitude and skills as a form of behavior change [4].

Developing an Inquiry model based on a learning model in accordance with the material can optimize the existing learning model, in addition to the fact that the development is intended to improve learning outcomes and to write scientific reports. Cooperative learning model that can be used as one of alternative strategies in learning. In learning with Inquiry, students are encouraged to have experience and conduct experiments that enable them to find principles for themselves. Based on the background, the author has been trying to develop a strategy based on a learning model called Inquiry to improve the learning outcomes and writing skills of scientific reports in the Biology Natural Science lesson at SMP Negeri 12 Samarinda.

\section{RESEARCH METHODS}

Research method used is Research and Development ( $R$ \& D). This method is used to fulfill the purpose of research that is to design and develop the Inquiry model by evaluating the quality and validity, validity and effectiveness in the learning process of Biology Science for grade VIII students. Sampling for this study is the state secondary school 12 Samarinda, and this study was conducted from March to August 2017. [7] states that "Research and Development" is a research to produce a product by trying its effectiveness. Bord and Gall [7] that "Research and Development" is a typical study used to develop and validate educational and learning products. Therefore, based on the experts, the typical R \& D research is now in line with the objectives of the study.

The procedures undertaken in this R \& D are based on Borg and Call and adopt the modified [7] $\mathrm{R} \& \mathrm{D}$ procedure. The sequence of learning models adopted based on Borg and Gall design by Sugiyono modification R \& D procedure (2013) is illustrated in the following Fig. 1.

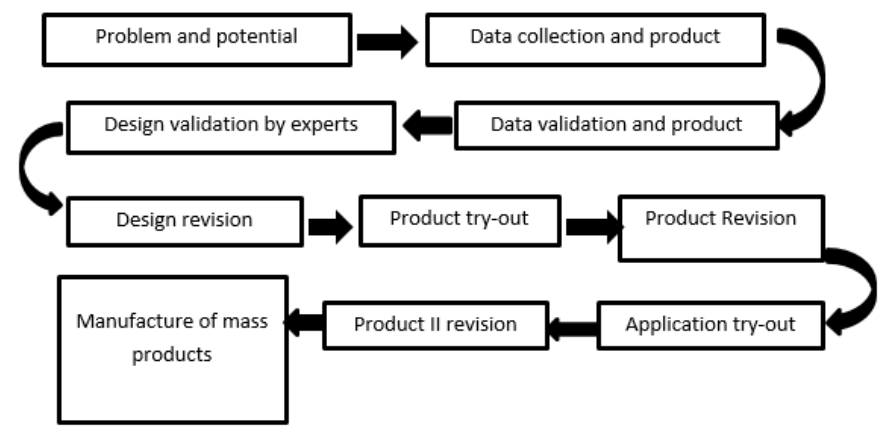

Fig. 1. Learning Model

The research subjects were State Junior High School 12 Samarinda as many as 52 students consisting of 13 students in limited trial and 39 students on wide field test (control class and experiment class).Technique of data analysis in this research, there are 3 method to get result. First assess the validity and quality of learning tools, both assess the practicality of the device and last assess the effectiveness of the learning tool. The validation learning tool by the experts on the learning model generated and produced in this way is the Value converted to percentage. Practicality is obtained from the student response questionnaire collected, whereas its effectiveness is taken from the percentage of improvement from pre to post test reached by the students.

\section{RESULTS AND DISCUSSION}

\section{A. Results}

\section{1) Identification of Problems and Potentials}

Identification of the problem and potential done to SMP Negeri 12 Samarinda. Based on the observation questionnaire about the conditions and problems faced by SMP Negeri 12 Samarinda, it was found that teachers at school experienced the following problems:

a) Teachers use conventional methods and learning devices that are used incompletely

b) Teachers already understand the writing of scientific reports but only just outline and rarely practiced

c) Teachers experience constraints when guiding students in writing scientific reports

d) Teachers are less aware of the steps to write a scientific report because there is rarely training

e) Teachers use teaching materials and student worksheets in the form of book packages from publishers

f) Teachers admit that all this time tends to learn in the classroom so rarely practice and write scientific reports

g) Students feel bored and bored so less attention when the teacher explained the subject matter

h) Students do not practice and write scientific reports

i) Student learning outcomes are mostly less than the minimum criterion criteria (KKM).

\section{2) Data Collection and Product Design}

Data were collected to find out what learning model the teacher had. What devices are owned by the teacher. At this stage the data obtained only syllabus and learning implementation plan. Therefore, the product of learning model is designed with attention to the teaching materials about circulation system in the eighth grade human. The expected outcomes in this development are syllabus, learning implementation plan, teaching materials, student worksheet, evaluation and assessment instrument.

\section{3) Design Expert Validation}

Inquiry-based learning model to improve learning outcomes and writing skills of scientific reports conducted then validated by experts. The validation team consists of products that validate the assessor, Dr. Achmad Fathoni, M.Pd, Professor of scientific endorsement, Prof. Dr. Daniel, M. Si, and the language that validates the appraisal by Dr. H. Yusak Hudiyono, M.Pd. The results obtained from all of these validations are $97.10 \%$ which is 'highly valid'.

\section{4) Revision Design}

Although the learning model is declared 'Very Valid', improvement is still needed for a better and systematic learning 
model. It is necessary to get the expected quality learning model. The design revisions were made on several sections, the results were repeatedly reviewed.

\section{5) Product Try-Out}

The try-out stage of the product is done to see how successful the learning model generated in this limited test can work. Students who follow small-scale test amounted to 13 students, while in large-scale test as many as 39 students. Class VIII A uses a learning model of Inquiry of circulatory system material in humans and taught by researchers, while class VIII B uses conventional learning model of circulatory system material in human being taught by teacher. Based on the output of homogeneity test SPSS from pretest and posttest data of control class VIII B obtained 0,505>0,05 mean that the mean value of pretest and posttest of control group have the same variant. While the results of homogeneity test calculations from the data value of pretest and posttest experimental class VIII A got $0.519>0.05$, the average value of pretest and posttest experimental group has the same variant.

\section{6) Product Revision I}

At the revision stage of product $\mathrm{I}$, in general has been good but there are some improvements to make the device better and better quality. Improvements made by adding pictures and information on the teaching materials section, giving additional time in the discussion on the implementation plan of learning. Subsequently gradually revised the product by consulting experts.

\section{7) Try-Out Application}

The experiments were conducted after the improvement of the learning device on product revision I. In the trial phase this usage was done by the researcher using the learning device that has been developed after being revised and limited to the students. Data of research result include result of pretest and posttest. Assessment results are analyzed using percentage improvement to determine whether there is an increase in learning between two samples of pretest and posttest students. Results of data analysis of student responses to 19 students then converted into percentages and obtained results $87.36 \%$. Based on the level of conversion of the test of practicality, score $87.36 \%$ indicates that the device is very practical for use in learning, so it can be said product development can help students to more easily understand the subject matter of the circulatory system in humans and write scientific reports.

\section{8) Product Revision II}

Based on the teacher input and suggestions on the teacher response questionnaire, the researcher made improvements by simplifying the language used on the student worksheet without reducing the points on the learning objectives. In addition, product revision II researchers also revised the lesson plan implementation (RPP) with time reduction in the delivery of the material at the beginning of the lesson so as to increase the time during the group discussion.

\section{9) Product Results}

Learning devices that have undergone product testing, revision, expert validation produce instructional tools based on Inquiry model to improve scientific report writing skill and learning outcomes through Biology Science learning ready to use. Learning tools are syllabus, learning implementation plan (RPP), teaching materials, student worksheets (LKS), evaluation and learning appraisal instruments that have been developed.

\section{DISCUSSION}

Researchers make observations and interviews to collect data and student needs that will be used to create the product. Based on the data obtained the researchers began to determine the model of learning that can be used to address the needs of students and learning materials in accordance with the model of learning selected by researchers.

Learning device development based on Inquiry learning model developed for class VIII SMP Negeri 12 Samarinda based on needs analysis and observation. Implementation of science biology teaching aims to increase creativity and understanding to the teacher about the importance of developing learning tools that have been owned so as to help facilitate teachers in teaching, helping students in the learning process and create a scientific report writing.

The results of observations made in SMP Negeri 12 Samarinda showed that the science teachers in the school amounted to three people. The education level of IPA Biology teacher at SMPN 12 Samarinda is undergraduate (S1) of Mathematics and Natural Sciences. Actually, the teacher has recognized the inquiry learning model but in reality the teacher still uses the conventional way when teaching in the classroom. The conventional way is to do the learning directly, lecture, and tend to monotone. Relevant to the opinion of Enggar (2012) states that the amount of science materials and curriculum demands that must be met cause teachers more often use the conventional approach with lecture methods, questioning, and assignments in learning. This happens because teachers tend to be less active and creative in exploring the capabilities possessed and less use of the natural environment around so that there are some models of learning written lesson implementation of learning less synchronized with the implementation in the classroom.

Teachers state that using Inquiry learning model takes more time to prepare instructional tools, students with diverse ability difficult to be conditioned, burden of teacher besides teaching still many other tasks to be completed. This should not happen if the teacher creates creativity / innovation and seeks the latest references using emerging technologies, utilizing the natural surroundings, and time management well.

Inquiry Learning encourages students to have experience and conduct experiments or labs that students enable to find principles for their own students. This is in line with Hofstein's (2004) opinion in [3] which states effective practicum activities to develop thinking logic, problem-solving skills, psychomotor improvement and student learning interest and avoid a monotonous learning environment.

Teachers' learning tools are also not complete, it is obtained from the statement of the vice principal in charge of the curriculum during discussions and interviews. Teachers are less prepared learning devices so that when there is a school accreditation teachers are busy making and completing 
learning tools. The teacher is only guided by the textbook of the publisher recommended by the school. The teacher should cover the deficiency with since the beginning of the year before the active learning process at school teachers have prepared the learning tool results from developing the learning tools that have so that the learning process can run well and according to the learning objectives. This is in accordance with the proposed by [9], that teachers should study the state of students, understand the weaknesses and advantages of students, and learn the initial knowledge of students. In addition, teachers also need to run learning activities in accordance with the implementation plan of learning and supported by other learning tools so that the ability and skills of teachers in the development of learning tools can increase.

Other problems faced are lack of mentoring in writing scientific reports and students also lack the ability to develop. Teachers teaching methods are monotonous so that students cause less focus and less interested in following the learning process. Students who are clever can condition themselves but for the less intelligent students experience the difficulty in receiving the subject matter so that students tend to like to play alone.

Based on the results of the above observations, the researcher can determine the model of learning and efforts to overcome the problem. The learning model chosen is the Inquiry model because the model can help the students remember the biology science material and can directly apply through the practicum so that it can easily write a scientific report. Efforts that can be done is to make the development of learning tools as reference materials, considerations and examples for teachers to be able to do device development in the future.

Inquiry learning model is a model of cooperative learning that is able to train students to solve problems using the steps that exist in the process of science and help facilitate teachers in the learning process. Inquiry is a series of learning activities that involves maximally all students' ability to search, and systematically, critically and logically investigate so that they can find their own knowledge, attitudes, and skills as a manifestation of behavioral change [4]. In Inquiry learning students are encouraged to be able to solve a problem by directly doing the practice so as to get its own experience. This is in line with Hofstein's (2004) opinion in [3] which states effective practicum activities to develop thinking logic, problem-solving skills, psychomotor improvement and student learning interest and avoid a monotonous learning environment.

Learning-based learning model Inquiry tools to improve the skills of writing scientific reports that have been completed in the form of syllabus, learning implementation plan (RPP), teaching materials, student worksheets (LKS), and evaluation and assessment instruments. Learning tools are then validated by a validation team of learning experts, material experts and language experts to identify product development validity. The developed learning tool gets some inserts from the validator team, then the researcher keeps improving the development product according to enter the validator team. The validation result is an average rating with a percentage of 97.10 and declared to be very valid, and feasible to use.

Stages after the subsequent validation process of learning tools are tested in limited to small groups with a total of 13 students. At that stage there are not many obstacles but there are some sentences and simplify the language that still needs to be diffuse, so that the next revision to make the learning devices produced better and quality.

The next stage after the revision is completed, the field test is done with two classes of control class and experimental class. The control class will be done by teachers using the device from the school in the conventional way, while the experimental class is done by the researcher using the developed device that is the instructional device based on Inquiry model. At the beginning of the learning done pre-test in both classes.

The next step is to test the homogeneity of pretest data on the control class and experiment class. Homogeneity test results will be used as a basis in determining the experimental class and control class, i.e. if the distribution of data obtained is homogeneous distributed then the sample selection used as the control class and the experimental class can be done by simple random sampling technique. Relevant to the opinion [7], that is said to be simple (simple) because the collection of sample members of the population is done randomly without regard to strata in the population. This is done when members of the population are considered homogeneous. Based on the calculation of homogeneity test, the significance value $0,505>$ 0,05 indicates that the pretest data is homogeneously distributed.

The implementation of the research begins with a written test that is pretest in two classes of product trials. Class VIII B / control class is taught by the teacher using the school device (teacher device), while the class VIII A / experimental class is taught by the researcher using the developed device.

The process of learning and practicum has been completed, then the test posttest is done on both samples to determine whether there are differences in results in both classes. Based on the result of posttest on both samples then analyzed by using independent test of sample t-test. Results obtained by the value of significance (2-tailed) $0.000<0.05$. This suggests that there is a significant difference in learning effectiveness between the experimental class and the control class. Thus it can be said that the learning process is more effective in class using the Inquiry model based learning device that has been developed.

The experimental class is more effective because the learning model is used in accordance with the needs of the students, the teacher interacts actively with the students, the discussion activities and the presentation with the group, the material is easy to understand, the students are more actively conveying the idea, the practice immediately followed by writing scientific report so that students make more creative and skilled in conducting experiments and can pour the results of his thoughts in the form of scientific reports. Relevant to Anam's opinion, (2015) states that inquiry-based learning is a learning model that provides free space for students to discover 
their passions and learning styles. Students are no longer forced to learn in a particular style, they are developed to be creative and productive learning. The positive value in this inquiry learning is that the students will not only know (know), but also understand (comprehend) the essence and potential - the development potential of certain learning materials.

Based on the results of the analysis of the assessment by the team of validator researchers have obtained products that are ready to be tested in school, after tested in the early stages there are still some shortcomings in the learning process: the instructions in the student worksheet less detail and simple, less understanding of writing scientific reports, so the researchers made some revisions in order to overcome the shortcomings of the product development.

The syllabus of the development consists of the school name, subject, class / semester, competency standard, basic competence, subject matter, learning activity, competency achievement indicator, assessment, time allocation, learning resource, expected student character. The syllabus of the development there is a more detailed learning activity that is by scientific approach (inductive) and based on inquiry model which include orientation, formulating problem, submitting hypothesis, collecting data, testing hypothesis, formulating conclusion thereby making it easier for teacher to make learning implementation plan. The expected outcomes of competency achievement indicators in the development syllabus are able to identify the characteristics of the circulatory system, the types of blood type, able to make reports on the practice of calculating the number of debut pulse and heart and making scientific reports about blood type tests. The expected character of the students is discipline, responsibility, respect and attention, cooperation, confidence, diligence, respect for the opinions of others, curiosity, so students are required to be a better person and able to meet all these aspects.

Implementation Plan Learning outcomes in the form of school identity, competency standards, basic competencies, indicators, learning objectives, expected student characteristics, learning materials, time allocation, learning strategies, learning activities, learning resources / teaching materials / learning tools.

Completeness of student learning outcomes can be said when completed and meet the KKM (minimal completeness criteria) that have been determined by the school. KKM standard score of 75.Results based on the analysis obtained in the trial class is limited the average value of pretest 28.69 and the average posttest value of 76.84 and the value of scientific report writing skills obtained an average of 70.61 and 79, 07. While in the control class obtained the average value of pretest 27.15 and the average value of posttest 66.35 and the value of scientific report writing skills obtained 68.6 and 71.8. Analysis conducted to find out the improvement of writing skill report and written test result using product of learning device development based on Inquiry learning model hence got result of average pretest of student equal to 31,47 and result of student average posttest equal to 79,26 and value skills of scientific report retrieval obtained 75.94 and 85.73 this indicates that the learning tools based on Inquiry model can improve the learning and writing skills of scientific reports. To see the meaning of the value then used percentage improvement analysis. Thus the skills of writing scientific reports have increased so that these activities can be used as a reference in the continuous learning process. Students have experience and insight in writing scientific report so that can be developed maximally to explore ability owned. The hope is that students are able to write individual scientific reports and follow the competition to write higher scientific works.

The final activity after giving the learning, the test evaluation, the practicum, and the writing of a scientific report, the researcher gave a questionnaire to each student. Questionnaires are given aims to determine the responses and assessments of students on the learning model that has been made by researchers. The result of the student response is said to be very practical with the average percentage of $87.36 \%$.

Learning device development based on learning model Inquiry to improve scientific report writing skill through Biology Science lesson in Class VIII SMP Negeri 12 Samarinda. Based on the results of the test and assessment analysis, the product development is stated very valid, effective and very practical can be used throughout the school and can improve the skills of writing scientific reports. But students still need guidance by teachers in every process of learning, practicum, and writing scientific reports because the role of teachers influence the progress and development of students.

\section{CONCLUSIONS AND SugGestions}

\section{A. Conclusion}

Based on the results of research and discussion, it can be concluded as follows:

- Design of learning tools based on learning model Inquiry to improve the skills of scientific report writing and learning outcomes through science learning Biology class VIII SMP Negeri 12 Samarinda consists of: syllabus, learning implementation plan, teaching materials, LKS, evaluation and assessment instruments.

- Instruction-based learning model Inquiry to improve the skills of scientific report writing and learning outcomes through science learning Biology class VIII SMP Negeri 12 Samarinda that has been developed to meet the validity of the learning kevalidan with the percentage of average assessment of the expert learning, material experts and language experts of $97.10 \%$, meet the criteria is very valid.

- Instruction-based learning model Inquiry to improve the skills of writing scientific reports and learning outcomes through science learning Biology class VIII SMP Negeri 12 Samarinda that has been developed to meet the practicality with the percentage of $87.36 \%$ based on the results of student responses that meet the criteria very practical.

- Instruction-based learning model Inquiry to improve the skills of scientific report writing and learning outcomes through science learning Biology class VIII SMP 
Negeri 12 Samarinda which has been developed proved effective use in the learning process, it can be seen from the improvement of students' learning achievement of $94.73 \%$ (increased by $34.73 \%$ ).

\section{B. Suggestions}

Teachers can use Inquiry learning model to improve the skills of scientific report writing and learning outcomes through Biology Science as an alternative learning in school. Then, researchers who will develop learning tools can make the product development of learning tools based on Inquiry learning model as a reference material and conduct a broader implementation.

\section{REFERENCES}

[1] Anam. 2015. Learning Model Inquiry. Jakarta: Brima Putra.

[2] Enggar, A. M., 2012. Development of Integrated IPA Learning Tool and Its Implementation Using Cooperative Learning Type STAD To
Improve Student Results of Junior High School (doctoral dissertation, Yogyakarta State University).

[3] Firdausi. 2014. Practical Learning. Bandung: Buwana Karya.

[4] Hanafiah, Nanang, Suhanah. 2010. Concept of Learning Strategy. Bandung: PT Redika Aditama.

[5] Kariawan, I. G. 2015. Development of Physics Learning Tool with Setting of Inquiry Learning Model to Improve Problem Solving Ability and Critical Thinking Ability of High School Students. e-Journal Graduate Program of Ganesha Investigation Unviersity. 5 (1).

[6] Slameto. 2003. Learning and Its Affecting Factors, Jakarta: Rineka Cifta.

[7] Sugiyono, 2011. Qualitative Quantitative Research Methods and R \& D. Bandung: Alfabeta.

[8] Suhadi. 2007. Learning Model Guidelines. Surakarta: Universitas Sahid Surakarta.

[9] Suparno. 2012. Educational Reform. Yogyakarta: Kanisius.

[10] Trianto. 2010. Integrated Learning Model. Surabaya: PT. Earth Script.

[11] Yaomi, Muhammad. 2013. Principles of Learning Design. Jakarta: PT Kencana. 